\title{
NOTES ON EARTHQUAKE INSURANCE IN CALIFORNIA AND NEW ZEALAND
}

\begin{abstract}
On the initiative of the Earthquake and War Damage Commission a team was organised to study the recovery from the earthquake which devastated Mexico City on 19 September 1985. Earthquake preparedness and underwriting in California was also researched. There were five members in the team and they were - Mr. Milton Allwood, Secretary of the Earthquake and War Damage Commission; Mr. Derek Scott, representing the Insurance Council of New Zealand; Mr. Ken Grieve, representing the Institute of Loss Adjusters of New Zealand (Inc): Mr. Edward Latter, National Director of Civil Defence; Mr. Don Currie, representing the Accident Compensation Corporation. The following extract on earthquake insurance is taken from one of the reports by the team.
\end{abstract}

\section{Californian Earthquake Insurance}

There are two markets for earthquake insurance in California, a market for the general public and a specialised commercial market.

Every insurer licenced in the state to transact residential property insurance is also required to offer earthquake protection, the offer lapsing if the consumer doesn't notify acceptance within 30 days of the offer being made.

Rates vary from 15 cents $\%$ to 20 cents of for wood framed dwellings and 20 cents to \$usl \% for masonry risks. Deductibles have until recently been $5 \%$ of the loss but are now being increased to $10 \%$, a movement which has received the consent of the state Insurance Department.

The Department also acknowledges that there are four factors to consider when underwriting residential risks viz: -

1. Type of construction - wood frame (including stucco) is much safer than masonry.

2. Age of house - post world war II California building codes require earthquake resistance construction. Thus the older homes are greater risks.

3. Proximity to faults - i.e. the closer to a fault line the greater the risk (there are over 100 fault lines in California).

4. Soil conditions - landfill, sandy soil, and hillsides are especially risky areas.

I was advised by the Assistant Insurance Commissioner that, notwithstanding the requirement to offer earthquake insurance to residential property owners, he acknowledges that some risks are not insurable. Provided that Insurers do not abuse this departure, there is unlikey to be any direction from the Department who otherwise would introduce "pooling".

The specialised commercial market is a free one without any direction on rating and it seems commercial rates vary from 25 cents $\%$ to 50 cents $\%$ depending on many more factors than those shown above for residential underwriting purposes.

Probable Maximum Loss Monitoring

Since 1980 the state Insurance Department has been compiling the aggregate insurance industry estimates of the probable maximum loss (PML) for an earthquake of the size of that which occurred in San Francisco in 1906 or Alaska in 1964; and publishes its findings in an annual report entitled California Earthquake Zoning and Probable Maximum Loss Evaluation Programme.

The PML's for commercial risks are between 6 and 7 times those for residential in San Francisco and between 8 and 9 times in Los Angeles. The 1985 report on 1984 PML's shows a substantial reduction in commercial PML's and about $10 \%$ increase in residential PML's explained to some extent by a 6.2 Richter magnitude earthquake near San Fernando in 1984 which induced land movement on steep hillsides.

Thus all insurers, including reinsurers, report with respect to their earthquake liabilities annually to the Actuarial Division of the Department of Insurance of California on a detailed basis laid down by the Department who believes that by promoting and encouraging the developement of improved methods of measuring the earthquake damage risk, a better earthquake insurance product will develop in terms of price and coverage. "It can be shown that certain types of 
homes, because of the construction and location, have a very limited risk of damage from earthquake. Such homes could have earthquake coverage at a nominal cost. other homes, on the other hand, have a demonstrably high risk of damage from earthquakes because of unreinforced masonry or located on landfill and must be insured at a higher premium and perhaps more restricted coverage. It may well be that some homes may not be readily insured except through a governmental mechanism...".

To quote further from the 1985 report - "the study of the threat of earthquake is an international effort, as earthquakes occur everywhere. (A total of 48 major earthquakes occurred around the world in 1984). Other governmental authorities are also working on economic and insurance solutions to the possibility of significant earthquake damage, particularly those countries which also border the Pacific Plate, such as Japan, New Zealand, and the South American countries." Current Californian Insurance Commercial

American International Underwriters advise that they write commercial earthquake business in California with deductibles ranging from $5 \%$ to $10 \%$ as a norm with a minimum of US\$250,000 on commercial builaings. Outside california the deductible would be $2 \%$ with a minimum of US\$100,000.

Rates varied but usually ran between 40 to 50 cents $\frac{\circ}{\partial}$ in California. Examples were inner city of San Francisco fire rates would be 10 cents $\%$ earthquake at least 18 cents $\%$ on high rise buildings.

This group have reduced their exposure in California last year (as have many of their competitors) from US\$300m to US\$204m and have also increased their rates substantially following the end of the soft market. Many lines have been dropped. Their maximum PML any one risk is now US\$5m.

An example of AIU underwriting: They are most reluctant to provide earthquake cover in silicone valley. One large influential client is insured with property fire cover of US\$34 m. Maximum cover provided for earthquake was US\$10m of which US\$5m was held to own account and US\$5m arranged facultatively. The HPR fire rate was 2 cents $\%$, the earthquake rate was 25 cents $\%$ with a $5 \%$ deductible.

Commercial Union in California operate a very tight earthquake catastrophe control programme and endeavour to divide their overall capacity into $35 \%$ personal lines and $65 \%$ commercial lines (buildings, contents, and business interruption).

Both companies use the Karl Steinbrugge approach (he is the guru on the science of earthquakes and probably maxium loss and is used as a consultant by the State Department of Insurance and also by Insurance Services office of California).
In other words, the Iso grading system for underwriting acceptance and direct relationship to PML is used by most insurers. Soil maps or microzoning is used and artificially reclaimed land, particularly around San Francisco, harbour areas, oil fields, and the like are avoided as much as possible.

I noticed that in some cases a US\$ $1 \mathrm{~m}$ liability translated to US\$400,000 PML and another US\$10 $\mathrm{m}$ was converted to a US\$3 $\mathrm{m}$ PML and that the Department considers residential contents PML is $50 \%$ of sum insured.

All insurers use earthquake inspection reports before accepting an earthquake risk, most using a special bureau of engineers who specialise in this area.

\section{New Zealand - The Risk of Earthquake}

Mexico is in a geographical zone which has a very heavy exposure to earthquakes whilst New Zealand is in one with heavy exposure.

The "average return period" or frequency of occurrence of earthquakes in New Zealand has been assessed by some seismologists at:-

MM VI every 6 years

MM VII every 21 years

MM VIII every 67 years

MM IX every 220 years

others apply a rough rule of thumb of Richter magnitude 7 every decade and a Richter magnitude 8 every 100 years which immediately gives the layman cause for concern as the Wairarapa earthquake of 1855 was assessed at 8 or $8+$.

on examining the approximate relationship between intensities on the Modified Mercalli scale and magnitudes on the Richter scale one could become easily confused until it is appreciated that this science is still in its infancy with a very narrow data base and thus predictions are inexact.

However we certainly cannot afford to be complacent and a major or great earthquake in our country is a probability. It is only a question of when.

Studies have been done to assess damage and loss of life (e.g. (i) Civdex Study 1972, (ii) Assessment of damage cost resulting from large earthquake in Wellington area - (Birss 1985). Much depends on the epi-centre, whether the earthquake is shallow or deep, type and duration and frequency of the shock waves, and soil resonance. The actual time of day of the earthquake can be very significant in assessing probability of injuries and deaths. (The Mexican September 1985 quake occurred at 7.18 a.m. Had it occurred several hours later, deaths have been estimated at 10 times more).

DSIR preliminary study of the microzoning in the Wellington area shows that the major part of our commercial and financial sector, central and civil 
administration buildings, railway yards, central telephone exchange and other key points sited between Lambton and Thorndon Quays, wharves, airport, and sewerage pipes are in zone 3 which have "high porosity sediment and significant amplification of incident vibration expected" which suggests liquifaction as experienced in Mexico City. This resulted in many buildings collapsing or being severely damaged including those designed to comply with Mexico City's 1977 seismic loadings code. It is also noted that our main access routes and major water supply follow the wellington fault line whilst many of the outlying hills are in the "topographic failure zone".

An assessment done for Institute of Loss Adjusters in 1980, assuming a Richter 7.9 in the Wellington area produced an estimate of 250,000 claims of which 160,000 were residential. Estimated cost of claims to the Commission alone was Nz\$2,000 m (currently the Fund stands at $\mathrm{NZl}, 200 \mathrm{~m} \cdot$ )

It should also be remembered that the area of most severe damage in Mexico City is about the size of Wellington Harbour.

Some seismologists believe that the Hutt Valey, Downtown Auckland, the environs of the old port of Dunedin, and the alluvial plains in Poverty Bay, Hawkes Bay, and Canterbury, could also have areas of potential liquifaction. It seems then that there is much more work to be done in the field of microzoning for earthquake effects and it is reassuring to see that the New Zealand National Society for Earthquake Engineering is studying the consequences of the Mexican earthquake after examining the damage first hand to determine whether New Zealand seismic design procedures and practice provides for proper defence against major earthquakes of this kind.

Insurers, then, must consider the protection afforded by them and by the Earthquake and War Damage Fund. Many consider the latter will prove to be totally inadequate to cope with a major earthquake in the vicinity of Wellington. There is somewhat less concern in respect of Auckland possibly because of the greater spread of risk. The existence of 63 volcanoes in that city, some dormant, raises the possiblity of the occurrence of natural disasters other than earthquake.

Whilst it would be prudent to raise the government earthquake levy of 5 cents (which is about $1 / 5$ of the rates charged in California for wooden framed dwellings) on contracts substantially for fire insurance, the future of the fund has been questioned recently by the parliamentary Undersecretary for Trade and Industry. It is possible that, instead of increasing levies, the fund could be restricted in time to protecting the residential market and leaving the entire commercial risk to the insurance industry, alternatively the Commission may eventually introduce a $25 \%$ coinsurance (this had a marked reduction in numbers of claims in Mexico) or increase existing deductibles in line with inflationary trends. Furthermore there is always the possibility that the Commission could enforce its rights in respect to classification of properties for earthquake resistance which could again result in $25 \%$ coinsurance being applied in certain cases or even suspension of cover. If any of these possibilities eventuated local insurers would soon meet with capacity problems as some worldwide reinsurers have indicated that their earthquake capacity for New zealand is full. This, I believe should be challenged as it seems unlikely that probable maximum loss assessment has been scientifically done on a national basis other than by overseas reinsurers applying their own formulae.

In assessing liabilities for earthquake, all policy lines should be considered including inwards reinsurance and coinsurance.

We must satisfy ourselves that not only are reinsurance arrangements adequate in respect to probable maximum losses but also that reinsurers will be able to meet their obligations, that their funds are invested in hard currencies, and that there are arrangements in force to release progress payments to New Zealand on account in the event of a major disaster.

The Mexican experience showed that inflation escalates following a major earthquake, the currency may weaken, and costs for the purchase of the necessary equipment to replace that lost will rise particularly if imported. Further consideration then should be given to the investing of the Government Earthquake and War Damage Fund overseas.

Direct insurers should insure that their own properties are earthquake resistant, that their internal funds are invested in earthquake resistant properties, and consider whether they will face serious problems if they have to sell their securities to pay off large losses if there is a significant drop in property values and securities following a major earthquake.

Some of these questions have already been raised by the Insurance Information Institute of New York in "A Guide for Businesses - How to Prepare for an Earthquake" illustrating the need for indepth studies on earthquake preparedness.

we should check whether our industry and in-house emergency plans are appropriate to a major disaster and whethere insurance company records, life and non-life, have adequate back-up should originals be lost or damaged.

The current insurance market practice of transacting earthquake risks is not very sophisticated and in most cases rates charged are totally inadequate on world standards. It is a great pity that we have departed from the structure which stood the test of many years as rates have been forced down to a level which is unlikely to provide a pool adequate to meet losses from other than a moderate earthquake. With the recent downwards movement of interest rates, surely the days of a soft insurance market and cash flow underwriting are numbered? 
We must now improve the selection, assessment, and underwriting of earthquake risks and consider introducing an element of self-insurance. Better still we should agree on a standard inspection report to be completed by a suitably qualified person and if necessary encourage the formation of a bureau along the lines of that operating in California.

Despite initial misgivings it does seem we can learn much from the Mexican experience, and from current insurance practice there and in California. As we offer the insuring public financial protection against losses caused by natural disasters, we must ensure beyond any doubt that it is there when most needed. seismologists would say that the sands of time are running out. 